\title{
Guidance and Counseling Comprehensive:
}

\author{
Evaluation Implemenation Guidance and Counseling Program
}

\author{
Agus Supriyanto \\ Guidance and Counseling Study Program \\ Universitas Ahmad Dahlan, UAD \\ Yogyakarta, Indonesia \\ agus.supriyanto@bk.uad.ac.id
}

\author{
Irvan Budhi Handaka \\ Guidance and Counseling Study Program \\ Universitas Ahmad Dahlan, UAD \\ Yogyakarta, Indonesia \\ irvan.handaka@bk.uad.ac.id
}

\begin{abstract}
Evaluation comprehensive guidance and counseling programs in Indonesia is carried out systematically in its assessment. Assessment can be found through implementation program guidance and counseling in aspects of planning, design, implementation, and evaluation in guidance and counseling programs, and components guidance and counseling program. The goal of this study is to describe the implementation of comprehensive guidance and counseling programs by school counselors. This research uses evaluation research. The approach used in the research is a systems approach that is focused on aspects of planning, implementation, and evaluate. Instruments used are questionnaire and documentation. Data analyzed using quantitative techniques. The finding showed that the implementation guidance and counseling program in high schools at the level of is still far from the expected standards $(\mathbf{5 8 . 4 \% )}$. Planning aspects guidance and counseling program at the level of is still far from the expected standard (54.69\%). Implementation aspects guidance and counseling program at the level of expected standards $(62.5 \%)$. The last aspect is evaluate aspect guidance and counseling program at the level of is still far from expected standards $(56.52 \%)$. So the recommendation is the teacher guidance and counseling in Indonesia as a come from graduates of guidance and counseling departement.
\end{abstract}

Keywords- discrepancy model, evaluation program, guidance and counseling comprehensive

\section{INTRODUCTION}

students is the individual in the process of developing into maturity or independence. To achieve maturity and independence, learners need guidance because students have less understanding or insight about himself, his environment, and experience in determining the direction of his life. The development of learners can't be separated from environmental influences, whether physical, psychological and social. The results show that social maturity contributed the highest in academic students achievement [1][2]

School counselors provide counseling programs in three critical areas: academic, personal/ social, and career. Their services and programs help students resolve emotional, social or behavioral problems and help them develop a clearer focus or sense of direction [3]. School counselors in the implementation of guidance and counseling programs need to be central figures. The role of school counselors is to develop the potential and competence of learners as the next generation of Indonesian nation that intellectual and moral. The hope is that counselors implement guidance and counseling programs must be compiled comprehensively.

Counselors should be able to implement comprehensive guidance and counseling programs in counseling and guidance services. Implementation of guidance and counseling programs in Indonesia currently uses a comprehensive guidance and counseling pattern. Components of comprehensive guidance and counseling programs are basic services (guidance curiculum), individual student planning, responsive services, and system support [4]. Guidace and counseling comprehensive helping all students become career ready requires a whole schoolcommunity approach [5]. Counselors can create an atmosphere of collaboration with parents conducted for student competence development as a force in the management system comprehensive guidance and counseling services [6][7][8].

School counselors as professionals to undertake guidance and counseling programs. The hope is the implementation of professional guidance and counseling programs. The results provide support that benefits for students associated with more complete implementation of comprehensive school counseling programs [9][10]. Expectations of guidance and counseling should be measured. Measurement of the implementation of guidance and counseling programs through evaluation. Evaluation of guidance and counseling programs described from the Guidelines for Performance Based Professional School Counselor Evaluation on the standards and criteria for the implementation of counseling and guidance services [11]. 
The method used is the method how to reach. The method of how to reach is based on identifying the desired program outcomes and identifying related characteristics and criteria. Scale rating, checklists, and questionnaires can be developed from these criteria and used to identify the extent to which the program is measured [12].

Planning guidance and counseling programs prepared by counselors based on need assessment. The counselor needs to carry out a need assessment to identify student needs. Information gathered from need assessment can help counselors to identify student needs. The results of the need assessment as a basis for developing comprehensive guidance and counseling programs. Implementation of guidance and counseling program based on planning of guidance and counseling program.

Implementation of guidance and counseling programs needs to be evaluated. The performance of school counselors in implementing counseling and guidance programs will prove their effectiveness in the event of student changes [13]. Aspects in counseling and guidance programs that need to be evaluated are (1) planning, (2) design, (3) implementation, and (4) evaluation [14]. To test the effectiveness and improve the guidance and counseling program it is necessary to evaluate. While the the logic model from ASCA identified six major clusters of activities (direct services, indirect services, school counselor personnel evaluation, program management processes, program evaluation processes and program advocacy) [15]. Evaluation of guidance and counseling programs can provide the resources needed to verify the strengths and weaknesses of counseling and guidance services [16].

Ideal conditions that have been implemented guidance and counseling programs have not been fully implemented in Indonesia. Various problems arise in terms of the implementation of counseling and guidance services that should be professionally implemented. Some studies have found that counselors have not been able to implement the counseling program as expected. The results showed that the implementation of counseling and guidance programs by counselors has not been in accordance with the expected, it is still lack the ability of counselors to handle and explore students' problems. Quantitative results showed that $39.47 \%$ of counselors were able to apply professional counseling skills in high category, while $60.53 \%$ were able to apply these skills in the moderate category [17].

The above phenomena indicate a gap between standards and criteria as ideal conditions with facts in the field in the implementation of counseling guidance and counseling program. It takes effort from counselors and related parties to overcome the gap between standards and criteria as ideal conditions with facts in Indonesia in terms of implementation of guidance and counseling programs. One effort that can be implemented is the evaluation of the implementation of comprehensive guidance and counseling programs. Evaluate the implementation of this comprehensive guidance and counseling program as an effort to fulfill the need to improve the quality of professional competence of counselor. The results of the evaluation of the implementation of comprehensive guidance and counseling programs in schools can be given recommendations as an effort to improve the implementation of guidance and counseling programs in schools to school counselors.

An evaluation model that can be used in evaluating the implementation of a comprehensive counseling and counseling program is the discrepancy model. This gap evaluation model was developed by Malcom Provus [18]. Provus explains the gap model evaluation aims to know between the level of conformity between the predetermined standard and the actual appearance of the program implementation. Evaluation as an ongoing process of information management that includes (1) agreement on certain standards; (2) determine the presence / absence of gaps that exist between the performance and some aspects of the program with standard tools for such performance; And (3) using information about gaps in deciding to develop or continue or discontinue the whole program or one aspect of the program [12].

There are two reasons for implementing a comprehensive guidance and counseling program using the gap model evaluation. The first reason is that this gap evaluation model is easy to implement in evaluating the implementation of comprehensive guidance and counseling programs. This is because the gap evaluation model uses a simple procedure. Second reason to use the gap evaluation model in conducting guidance and counseling program evaluations is relatively less time and cost than other evaluation models.

This gap evaluation model seeks to see the gap between the performance of the comprehensive guidance and counseling programs that school counselors have done with the standards and evaluation criteria of the comprehensive guidance and counseling programs that have been developed. The standards and criteria for the implementation of comprehensive guidance and counseling programs are referred from Guidelines for Performance Based Professional School Counselor Evaluation [19]. Establishment of guidance and counseling evaluation is the formulation of recommendations on the sustainability of counseling and guidance programs in Indonesia.

\section{METHOD}

This study uses evaluation research. The evaluation conducted in this study uses an evaluation with a discrepancy-oriented model of a decision to assist administrators in making decisions. The approach used is a system approach that is focused on planning, implementation, and evaluation of guidance and counseling programs in SMA. 
Discrepancy model is an evaluation model developed by Malcom Provus. Provus defines evaluation as a process of (1) defining program standards; (2) determine the difference between performance and standard; (3) using nonconformities as materials to change the performance or program standards. Thus, it can be used as a formative assessment to determine the quality of the implementation of counseling and guidance programs as well as the quality of the counselor as a qualified expert guidance and counseling service. Guidelines for evaluating program guidance and counseling programs using program evaluation standards from Guidelines for Performance Based Professional School Counselor Evaluation.

The instrument used in this study is a questionnaire with the support of documentation at the time of conducting the evaluation. Research subject in this research is school counselor at high school level in student city, Yogyakarta, Indonesia. The component evaluated in this research is the comprehensive component of guidance and counseling program implementation. These components are aspects of program planning, program implementation aspects, and program evaluation aspects.

Questionnaires in this study included in the type of closed questionnaire because it has provided answers so that respondents only choose one alternative answer. Questionnaires in this study are divided into three aspects namely aspects of planning, implementation, and evaluation of the program. While the documentation in this research is in the form of service unit documents covering annual, semiannual, monthly or weekly program, service delivery plan, service material, and evaluation. This method is used to obtain supporting data relevant to the research theme.

Validity test in this research use correlation technique Product Moment $\left(\mathrm{r}_{\mathrm{ix}}\right)$ from Karl Pearson. Then the reliability of the research instrument was tested using the coefficient formula Cronbach's Alpha. The higher the reliability coefficient is approaching one, the more reliable the measuring tool used. Statistical analysis method used in this research is descriptive analysis.

\section{RESUlT AND DISCUSSION}

The results of this study indicate that evaluation of guidance and counseling program implementation at school counselor in high school level. Aspects that are replicated in accordance with the components of the implementation of comprehensive guidance and counseling programs. Aspects of the implementation of comprehensive guidance and counseling programs are aspects of planning, implementation aspects, and evaluation aspects.

Data of research result from data analysis on planning aspect, implementation aspect, and evaluation aspect can be seen in following table.
TABLE I. Result of Aspect Analysis of Planning Guidance and Counseling Program

\begin{tabular}{|c|c|c|c|}
\hline Indicator & Descriptor & Percentage & Standard \\
\hline \multirow{2}{*}{$\begin{array}{c}\text { Conducting } \\
\text { study of student } \\
\text { needs on } \\
\text { guidance and } \\
\text { counseling } \\
\text { program }\end{array}$} & $\begin{array}{l}\text { Develop an instrument } \\
\text { to carry out a student } \\
\text { needs study }\end{array}$ & $52,22 \%$ & $\begin{array}{l}\text { Far below set } \\
\text { standards }\end{array}$ \\
\hline & $\begin{array}{l}\text { Carry out instrument } \\
\text { analysis as the basis } \\
\text { for formulating } \\
\text { guidance and } \\
\text { counseling programs }\end{array}$ & $42,74 \%$ & $\begin{array}{l}\text { Far below set } \\
\text { standards }\end{array}$ \\
\hline \multicolumn{4}{|c|}{$50,94 \%$ (Far below set standards) } \\
\hline \multirow[t]{3}{*}{$\begin{array}{l}\text { Develop } \\
\text { guidance and } \\
\text { counseling } \\
\text { programs }\end{array}$} & $\begin{array}{l}\text { Develop an annual and } \\
\text { semester program of } \\
\text { counseling and } \\
\text { counseling }\end{array}$ & $54,84 \%$ & $\begin{array}{l}\text { Far below set } \\
\text { standards }\end{array}$ \\
\hline & $\begin{array}{l}\text { Preparation of Service } \\
\text { Delivery Plan with } \\
\text { service materials } \\
\text { according to the } \\
\text { problems / needs of } \\
\text { students }\end{array}$ & $69,35 \%$ & $\begin{array}{l}\text { Approaching the } \\
\text { set standards }\end{array}$ \\
\hline & $\begin{array}{l}\text { Arrange schedule of } \\
\text { implementation of } \\
\text { guidance and } \\
\text { counseling program }\end{array}$ & $55,65 \%$ & $\begin{array}{l}\text { Far below set } \\
\text { standards }\end{array}$ \\
\hline \multicolumn{4}{|c|}{$65,93 \%$ (Far below set standards) } \\
\hline \multicolumn{2}{|c|}{ Aspects of Planning } & \multicolumn{2}{|c|}{$\begin{array}{c}54,69 \% \text { (Far below set } \\
\text { standards) }\end{array}$} \\
\hline
\end{tabular}

TABLE II. Result of Aspect Analysis of Implementation Guidance and Counseling Implementation

\begin{tabular}{|c|c|c|c|}
\hline Indicator & Descriptor & Percentage & Standard \\
\hline \multirow[t]{2}{*}{$\begin{array}{l}\text { Relevance of } \\
\text { guidance and } \\
\text { counseling } \\
\text { programs }\end{array}$} & $\begin{array}{l}\text { Carry out support } \\
\text { activities in guidance } \\
\text { and counseling } \\
\text { programs. }\end{array}$ & $56,94 \%$ & $\begin{array}{l}\text { Far below set } \\
\text { standards }\end{array}$ \\
\hline & $\begin{array}{l}\text { Carry out services in } \\
\text { counseling and } \\
\text { guidance programs. }\end{array}$ & $63,31 \%$ & $\begin{array}{l}\text { Approaching } \\
\text { the set standards }\end{array}$ \\
\hline \multicolumn{4}{|c|}{$58,76 \%$ (Far below set standards) } \\
\hline \multirow{2}{*}{$\begin{array}{l}\text { Collaborate with } \\
\text { relevant parties to } \\
\text { support the } \\
\text { success of } \\
\text { guidance and } \\
\text { counseling } \\
\text { programs }\end{array}$} & $\begin{array}{l}\text { Collaborate with } \\
\text { fellow educators in } \\
\text { implementing } \\
\text { guidance and } \\
\text { counseling programs. }\end{array}$ & $70,65 \%$ & $\begin{array}{l}\text { Approaching } \\
\text { the set standards }\end{array}$ \\
\hline & $\begin{array}{l}\text { Collaborate with } \\
\text { parents, communities, } \\
\text { and institutions outside } \\
\text { the school in } \\
\text { implementing } \\
\text { counseling and } \\
\text { guidance programs }\end{array}$ & $65,86 \%$ & $\begin{array}{l}\text { Approaching } \\
\text { the set standards }\end{array}$ \\
\hline \multicolumn{4}{|c|}{$68,85 \%$ (Approaching the set standards) } \\
\hline \multirow{2}{*}{$\begin{array}{l}\text { Completeness } \\
\text { and use of } \\
\text { facilities and } \\
\text { infrastructure to } \\
\text { support the } \\
\text { success of } \\
\text { guidance and } \\
\text { counseling } \\
\text { programs }\end{array}$} & $\begin{array}{l}\text { Utilizing the media in } \\
\text { implementing } \\
\text { guidance and } \\
\text { counseling programs. }\end{array}$ & $58,60 \%$ & $\begin{array}{l}\text { Far below set } \\
\text { standards }\end{array}$ \\
\hline & $\begin{array}{l}\text { Utilizing facilities and } \\
\text { supporting facilities in } \\
\text { implementing } \\
\text { guidance and } \\
\text { counseling program. }\end{array}$ & $56,05 \%$ & $\begin{array}{l}\text { Far below set } \\
\text { standards }\end{array}$ \\
\hline \multicolumn{4}{|c|}{$\mathbf{5 7 , 5 8 \%}($ Far below set standards) } \\
\hline \multicolumn{2}{|c|}{ Aspects of Implementation } & \multicolumn{2}{|c|}{$\begin{array}{c}62,5 \% \text { (Approaching the set } \\
\text { standards) }\end{array}$} \\
\hline
\end{tabular}


TABLE III. Result of Aspect Evaluation Analysis in Guidance and Counseling Program

\begin{tabular}{|c|c|c|c|}
\hline Indicator & Descriptor & Percentage & Standard \\
\hline \multirow{2}{*}{$\begin{array}{l}\text { The presence of } \\
\text { follow-up to } \\
\text { students who } \\
\text { have received } \\
\text { services from } \\
\text { guidance and } \\
\text { counseling } \\
\text { programs }\end{array}$} & $\begin{array}{l}\text { Conducting an } \\
\text { evaluation of the } \\
\text { implementation of } \\
\text { guidance and } \\
\text { counseling programs. }\end{array}$ & $49,19 \%$ & $\begin{array}{l}\text { Far below set } \\
\text { standards }\end{array}$ \\
\hline & $\begin{array}{l}\text { Monitoring the impact } \\
\text { of the implementation } \\
\text { of guidance and } \\
\text { counseling programs } \\
\text { on changes in student } \\
\text { behavior. }\end{array}$ & $63,98 \%$ & $\begin{array}{l}\text { Approaching } \\
\text { the set } \\
\text { standards }\end{array}$ \\
\hline \multicolumn{4}{|c|}{$56,59 \%$ (Far below set standards) } \\
\hline \multirow[t]{2}{*}{$\begin{array}{l}\text { Collaborate with } \\
\text { the principal in } \\
\text { evaluating } \\
\text { counseling and } \\
\text { guidance } \\
\text { programs }\end{array}$} & $\begin{array}{l}\text { Develop results of } \\
\text { evaluation of guidance } \\
\text { and counseling } \\
\text { program } \\
\text { implementation. }\end{array}$ & $57,06 \%$ & $\begin{array}{l}\text { Far below set } \\
\text { standards }\end{array}$ \\
\hline & $\begin{array}{l}\text { Convey the } \\
\text { composition of the } \\
\text { evaluation results of } \\
\text { guidance and } \\
\text { counseling programs } \\
\text { to the principals and } \\
\text { stakeholders to get } \\
\text { feedback. }\end{array}$ & $55,24 \%$ & $\begin{array}{l}\text { Far below set } \\
\text { standards }\end{array}$ \\
\hline \multicolumn{4}{|c|}{$56,45 \%$ (Far below set standards) } \\
\hline & Aspects of Evaluation & \multicolumn{2}{|c|}{$\begin{array}{c}\mathbf{5 6 , 5 2 \%} \text { (Far below set } \\
\text { standards) }\end{array}$} \\
\hline
\end{tabular}

The research findings show that the implementation of guidance and counseling program in senior high school is at the level is still far from the standard, that is $58.4 \%$. In particular the aspect of planning aspects of guidance and counseling program planning is at the level is still far from the standard, is $54.69 \%$. The implementation aspect of the guidance and counseling program is at the level close to the expected standard of $62.5 \%$. While the evaluation aspect of guidance and counseling program is at the level still far from the expected standard, that is $56,52 \%$.

The study shows that the implementation of guidance and counseling programs has not met the specified standards. The results are in accordance with the findings of other studies that have been done. The results showed that evaluation of the implementation of guidance and counseling programs in junior high school as Palangka Raya city lesson year 2013/2014 which includes services to learners, services to subject teachers, services to principals, and services to parents of learners as follows: (1) 16 types of counseling and guidance programs or $(59.26 \%)$ programs performed very well, (2) 8 types of guidance and counseling programs or $(29.63 \%)$ programs implemented well, (3) 1 type of service program Guidance and counseling or $(3.70 \%)$ of the programs are implemented adequately, and (4) 2 types of counseling and guidance programs or $(7.41 \%)$ programs are implemented with less [20].

The results of the study further indicate the need assessment of counseling guidance program in the category of excellent tutoring, but the guidance and counseling teachers do not know how to standarize the instrument with computer software program [21]. Research also recommends to counselors to improve the quality of the counseling program implementation, thus providing a positive influence for students. The study also recommends that guidance and counseling teachers learn to standardize instruments, and information technology skills.

Then the results of subsequent research showed that the results obtained from the data processing showed that the program of guidance and counseling services at primary school Muhammadiyah Surabaya using the program adopted from the general government program for high school is 17 plus pattern, which is reduced or added in accordance with the needs of students School respectively. While the implementation of guidance and counseling services include: planning, implementation, evaluation and follow-up. From each school different results obtained because the content of the program and its implementation was different in each school, although it can be said that the implementation of guidance counseling services in primary school Muhammadiyah Surabaya already programmed and planned although not running well and maximum [22].

The gap between guidance and counseling performance with predetermined standards is due to several factors. First, "model of guidance and counseling comprehensive program that developed is effective to evolving the personality/ social competency of secondary high school students. Therefore it, counselor need to have leadership ability, create an collaboration atmosphere between stakeholders, and tecnology information mastered. [23]." Counselors as professionals are powerless to implement guidance and counseling programs in four professional areas of counseling (personal, career, learning and social). The helplessness of this counselor is indicated by the low mastery of the counselor in the planning, implementation, and evaluation of previously prepared programs.

Second, the reluctance of counselors to collaborate with stakeholders, especially parents in the implementation of guidance and counseling programs in secondary schools. "Collaboration counselor with parents conducted for student spiritual competence development through comprehensive guidance and counseling services" [8].

Third, the implementation of counseling and guidance programs that have not met the established standards, if associated with the findings in the field is strongly related to the low supervision of guidance and counseling programs. Infrastructure policy for guidance and counseling is complete enough although not maximized due to lack of budget funds. Guidance and counseling allocation time policy, the percentage is $20 \%$ no guidance and counseling hours at all, $40 \%$ of all classes have hours of guidance and counseling, while the other $40 \%$ is only part of the class. Policy on the academic qualifications of counselors, $50 \%$ of all guidance and counseling teachers with guidance and counseling educational background, and $50 \%$ others non 
guidance and counseling. Almost all guidance and counseling teachers have met the criteria of guidance and counseling teacher workload that is minimum of 150 students. Guidance and counseling supervision by the principal is still not optimal. The assumption of guidance and counseling as a school police has begun to disappear because of the policy of the principal who sets the teacher guidance and counseling should not punish the students. The conclusion of the research is that generally the principal already knows the role and responsibilities of the principal to the guidance and counseling service, but in the implementation the principal lacks the understanding and lacks the needs of guidance and counseling teachers and students [24].

Practice in the field shows the reluctance of the counselor to do self-reflection. Counselors in the field too confident that he has provided optimal service through guidance and counseling programs. Over Confidince is present in the counselor because the benchmark of individual counseling service program success is the low number of students who request counseling services on the counselor. This is reinforced by the reluctance of students to further deal with counselors primarily to obtain additional consultation services because the consultation services are considered not to be much of a change.

The low self-reflection performed by the counselor is influenced by several factors. First, the mental attitude of the counselor who considers the experience he has as a guarantee of quality and success of the program implementation. Second, the identity of the counselor's identity as a professional profession, which resulted in the development of personality counselor always to always reflect every act of service provided.

\section{CONCLUSION}

The results of this study indicate that there are three aspects that are evaluated, namely aspects of program planning, program implementation, and program evaluation aspects. Three aspects as a whole in the implementation of guidance and counseling programs by school counselors in Indonesia. The conclusions of each aspect are:

1. Planning aspects of guidance and counseling program at the level is still far from the standard, is $54.69 \%$.

2. The implementation aspect of the guidance and counseling program is at the level close to the expected standard of $62.5 \%$.

3. The evaluation aspect of guidance and counseling program is at the level is still far from the expected standard, that is $56,52 \%$.

4. Implementation of guidance and counseling programs by high school counselors is at the level is still far from the standard, that is $58.4 \%$.

\section{ANKNOWLEDGMENT}

Through this article, the authors would like to thank the school counselors in Yogyakarta youth city for their cooperation as the proper research. The hope of this research is as a recommendation in developing the quality of school counselor to be able to carry out comprehensive guidance and counseling program.

\section{REFERENCES}

[1] S. S. Puar \& P. Thukral, Role of Social Maturity in Academic Achievement of High School Students. International Journal of Educational and Psychological Research, vol.1(1), Pp.6-11, 2012.

[2] V. Nagra \& M. Kaur, Social Maturity among Student Teachers. International Journal of Education and Psychological Research (IJEPR), vol. 2(1), Pp. 10-16, 2013.

[3] American Counseling Association, Efeevtiveness of School Counseling Research. Alexandria, USA: American Counseling Association, 2007.

[4] N. C. Gybers \&, P. Henderson, Developing \& Managing Your School Guidance and Counseling Program. Alexandria, USA: American Counseling Association. 2012.

[5] N. C. Gysbers, Career-Ready Students: A Goal of Comprehensive School Counseling Programs. The Career Development Quarterly, vol. 61(3), Pp. 283-288, 2013.

[6] A. Supriyanto, Kolaborasi Konselor, Guru, dan Orang Tua Untuk Mengembangkan Kompetensi Anak Usia Dini Melalui Bimbingan Komprehensif. Jurnal CARE (Children Advisory Research and Education), vol. 4(1), Pp. 1-8, 2016.

[7] A. Supriyanto, \& A. Wahyudi, Kolaborasi Konselor dan Stakeholders (Landasan Pengembangan Program Bimbingan dan Konseling Komprehensif). In Prosiding Seminar Nasional 2016" Penguatan Kinerja Konselor dalam Menghadapi MEA" pp. 67-76, 2016

[8] A. Supriyanto, Collaboration Counselor and Parent for Developing Student Spiritual Competency trough Comprehensive Guidance and Counseling Service. Jurnal Fokus Konseling, vol. 2(1), Pp.48-59, 2016.

[9] J. Carey, K. Harrington, I. Martin, \& D. Hoffman, A Statewide Evaluation of The Outcomes of The Implementation of ASCA National Model School Counseling Programs in Rural and Suburban Nebraska High Schools. Professional School Counseling, 16(2), Pp. 100-107, 2012.

[10] J. Carey, K. Harrington, I. Martin, \& D. Stevenson, A Statewide Evaluation of The Outcomes of The Implementation of ASCA National Model School Counseling Programs in Utah High Schools. Professional School Counseling, 16(2), 89-99, 2012.

[11] Missouri Department of Elementary and Secondary Education, Guidelines for Performancebased Professional School Counselor Evaluation. Jefferson City, MO: Author, 2000.

[12] Fitzpatrick L. J., Sanders R. J., \& Worthen R. B, Program Evaluation Alternative Approcahes and Guidelines. USA: Pearson Education, Inc, 2004.

[13] R.L. Astramovich \& J.K. Coker, Program Evaluation: The Accountability Bridge Model for Counselors. Journal of Counseling \& Development, vol 85: Pp. 162-172, 2007

[14] A. Supriyanto, \& I. B. Handaka, Profesionalisme Konselor: Evaluasi Program Bimbingan Dan Konseling Komprehensif di Sekolah. Prosiding Seminar Nasional LP3M, Pp. 81-89, 2016

[15] I. Martin, \& J. Carey, Development of a Logic Model to Guide Evaluations of the ASCA National Model for School Counseling Programs. Professional Counselor, vol 4(5), Pp. 455-466, 2014.

[16] C.N.C. Otto, An Evaluation of the School Counseling Program at Stillwater Area Schools in Stillwater, Minnesota. University of Wisconsin-Stout: The Graduate College, 2001 
[17] A, Akhmadi, Peningkatan Kemampuan Konselor Profesional, Kajian Materi Diklat Jarak Jauh Guru Bimbingan Konseling, 2012 [Online,
Oktober
Accessed
from:

12
http://www.himcyoo.files.wordpress.com

[18] C. McKenna, Making Evaluation Manageable. Journal of Extention. Pp. 1-14, 1981

[19] Missouri Department of Elementary and Secondary Education, Guidelines for Performancebased Professional School Counselor Evaluation. Jefferson City, MO: Author, 2000.

[20] T. Yusuf, \& M. Fatchurahman, Evaluasi Pelaksanaan Program Bimbingan dan Konseling pada Sekolah Menengah Pertama di Kota Palangka Raya. Pedagogik Jurnal Pendidikan, Vol. 9(2), pp. 90-101, 2014.

[21] C. T. Anni, Need Assesment Model Penyusunan Program Bimbingan dan Konseling Bidang Bimbingan Belajar Berbantuan Sistem Informasi Manajemen Di SMA Negeri Kota Semarang. Educational Management, Vol. 1(1), 2012.

[22] Y. A. Puspitaningsih, \& M. Nursalim, Pelaksanaan Program Layanan Bimbingan dan Konseling di SD Muhammadiyah se Surabaya. Jurnal Mahasiswa Teknologi Pendidikan, Vol. 10(2), 2009.

[23] A. Sutoyo, \& A. Supriyanto, Development Personality/Social Competency of Secondary High School Students trough A Comprehensive Guidance and Counseling Program. Jurnal Fokus Konseling, Vol. 1(2), 2015.

[24] D. R. A. Mahanggi,, Kebijakan Kepala Sekolah Terhadap Pelayanan Bimbingan Konseling di SMA Negeri Se-Kabupaten Purbalingga. Indonesian Journal of Guidance and Counseling: Theory and Application, Vol. 3(1), 2014. 